\title{
AMAR
}

AMAR (Andalas Management Review)

Vol. 2, No. 2 (2018) 1-10

The Management Institute, Faculty of Economics, Universitas Andalas

ISSN (Print) 2476-9282 | ISSN (Online) 2548-155X

\section{Persepsi Kualitas Produk, Persepsi Harga dan Promosi Terhadap Keputusan Pembelian Tas Sophie Paris pada Mahasiswa}

\author{
Sumiatia , Siti Mujanah ${ }^{\mathbf{b}}$ \\ aUniversitas 17 Agustus 1945 Surabaya, sumiatife@untag-sby.ac.id \\ bUniversitas 17 Agustus 1945 Surabaya, sitimujanah@untag-sby.ac.id
}

\begin{abstract}
This research is inspired by the phenomenon of fashion development nowadays which is increasingly attractive and becomes a part of everyday life, especially when fashion is considered as an identity and needs that must be met, one of which is a bag. The purpose of this research is to find out some of the factors that influence the Sophie Paris bags' purchase decision. The method used in this research is quantitative with data sources taken directly from 17 August 1945 University students wearing Sophie Paris bags. Data were collected by distributing questionnaires to one hundred respondents using simple random sampling technique. The results of the analysis obtained from this study are that the perception of product quality has a positive and significant effect on purchasing decisions, price perceptions have a negative and insignificant effect on purchasing decisions, promotion has a positive and significant effect on purchasing decisions. Simultaneously, perceptions of product quality, price perceptions, and promotions influence purchasing decisions. Promotion variables have the most dominant influence in purchasing decisions for Sophie Paris bags. By looking at the variables that influence the decision to buy bags, price is the variable with the lowest influence, therefore Sophie Paris is advised by the company to provide price variations according to the target market segmentation starting from the upper, middle and lower class.
\end{abstract}

Keywords: Product Quality Perception, Price Perception, Promotion, Purchase Decision.

\section{PENDAHULUAN}

Perkembangan fashion di Indonesia sudah sangat pesat, diikuti dengan trend yang menjadi bagian dari kehidupan sehari - hari saat ini. Fashion merupakan suatu aspek yang dinilai dapat menunjang penampilan. Dampak dari adanya persepsi tersebut tentu saja membuat masyarakat beralih mengikuti trend yang ada, bahkan bukan hanya sekedar mengikuti tapi sudah menjadi kebutuhan dari masyarakat modern saat ini untuk tampil trendi. Kegunaan lain dari fashion juga bukan hanya sebagai penutup tubuh saja, namun menjadi suatu kebutuhan untuk menyampaikan identitas diri.

Menyadari hal tersebut, produsen menciptakan inovasi dalam bentuk produk tas yang diharapkan mampu memenuhi selera konsumen dalam bidang fashion. Khususnya 
untuk kalangan mahasiswa yang menginginkan desain tas modern dengan kualitas yang baik dan cocok untuk digunakan dalam berbagai aktivitas maupun di acara apapun. Maka dari itu setiap perusahaan harus bekerja keras untuk mencapai tujuan dengan memasarkan produknya dan salah satunya yaitu dengan menyusun strategi pemasaran yang tepat.

Pengertian pemasaran menurut Kotler dan Armstrong (2015) bahwasanya"Marketing as the process by which companies create value for customers build strong customer relationships in order to capture value fromcustomers in return". Maksud dari pengertian tersebut adalah pemasaran sebagai proses dimana perusahaan menciptakan nilai bagi pelanggan dan membangun pelanggan yang kuat relationship untuk menangkap nilai dari pelanggan sebagai imbalan.

Pemasaran sangat penting dalam siklus yang berhubungan dengan kebutuhan konsumen. Dalam sebuah perusahaan, pemasaran merupakan salah satu dari kegiatan pokok yang dilakukan perusahaan untuk mempertahankan produknya agar berkembang dan mendapatkan keuntungan sesuai target, kegiatan pemasaran perusahaan juga harus dapat memberikan kepuasan terhadap konsumen jika mengharapkan usaha dan produknya berkembang dengan baik.

Sejak semua orang mengerti kegiatan pemasaran, para ahli mengemukakan definisi tentang pemasaran yang terlihat berbeda tetapi memiliki arti yang sama. Perbedaan ini disebabkan karena mereka memandang pemasaran dari segi - segi yang berbeda. Dapat dimengerti bahwa kegiatan pemasaran adalah kegiatan - kegiatan yang saling berhubungan dengan orang lain sebagai suatu sistem. Kegiatan pemasaran tersebut beroperasi dalam suatu lingkungan yang terus berkembang sebagai konsekuensi hubungan antara perusahaan maupun produk yang sama atau antar perusahaan yang berbeda, yang dapat mengakibatkan persaingan tetapi juga dapat dibatasi oleh sumber daya dari perusahaan dan peraturan yang ada.

Setiap perusahaan perlu memahami kelangsungan hidup perusahaan tersebut sebagai organisasi yang berusaha memenuhi kebutuhan dan keinginan konsumen (Tjiptono, 2008). Khususnya dibidang penjualan tas, perusahaan harus mampu memahami selera konsumen seperti apa, karena kebanyakan pesaing yang ada saat ini adalah jenis tas yang brendnya sudah banyak diminati oleh kalangan wanita, dari remaja hingga orang tua. Ketatnya persaingan mengharuskan pihak manajemen untuk selalu berorientasi pada kepentingan konsumen dengan memahami dan mengenal berdasarkan perilaku konsumen tentang pemahaman atas apa yang menjadi kebutuhan dan untuk meraih pangsa pasar yang lebih besar. Dalam pencapaian keberhasilan perusahaan pada strategi pemasaran perlu didukung 
pemahaman yang baik mengenai strategi perusahaan, karena dengan menentukan rencana dan menerapkannya pada kondisi yang tepat perusahaan dapat menyusun strategi dengan mengetahui apa saja yang menjadi kebutuhan dan keinginan konsumen. Penyusunan strategi perusahaan hubungannya berkaitan dengan pengambilan keputusan suatu produk atau jasa, pemahaman mengenai kebutuhan yang diharapkan konsumen meliputi jawaban atas pertanyaan seperti apa (what) yang dibeli, dimana dibeli (where), bagaimana kebiasaan (how often), membeli dan dalam keadaan apa (under what codition) barang - barang dan jasa dibeli dengan mengetahui target pasar dan menerapkan stategi yang tepat pada konsumen diharapkan dapat mempengaruhi keputusan pembelian konsumen terhadap suatu produk.

Menurut Kotler \& Keller (2016) Pemasaran berkaitan dengan proses mengenali serta memenuhi beragam kebutuhan manusia dan masyarakat. Secara singkat pemasaran ialah "meeting needs profitably", artinya pemsaran ialah memenuhi kebutuhan secara menguntungkan. Komunikasi pemasaran adalah sarana yang digunakan oleh perusahaan untuk menginformasikan, membujuk, dan mengingatkan konsumen terkait dengan produk yang ditawarkan.

Perusahaan harus memulai usahanya berawal dari sebuah produk, artinya perusahaan harus mampu mengenal produk yang akan menjadi kebutuhan dan harapan konsumen pada saat ini maupun yang akan datang. Perusahaan harus memulai usahanya berawal dari sebuah produk, artinya perusahaan harus mampu mengenal produk yang akan menjadi kebutuhan dan harapan konsumen saat ini maupun yang akan datang. Konsumen sebagai individu dalam hubungannya terhadap pengambilan keputusan pembelian suatu produk atau jasa, telah melalui proses atau tahapaan - tahapan terlebih dahulu seperti mendapat informasi atau referensi dari orang lain kemudian membandingkan produk sampai akhirnya pada keputusan membeli produk. Proses pengambilan keputusan pembelian pada setiap orang pada dasarnya adalah sama, namun proses pengambilan keputusan tersebut akan diwarnai oleh ciri kepribadian, usia, pendapatan dan gaya hidupnya. Menurut Schiffman \& Kanuk (2008) secara umum keputusan pembelian adalah seleksi dari dua atau lebih pilihan alternatif. Berdasarkan pendapat diatas, istilah keputusan pembelian dapat diartikan sebagai bagian pemilihan dari perbandingan yang ada yang bertujuan untuk memilih dan membeli barang dimana individu terlibat secara langsung untuk melakukan proses pembelian diantara banyak pemilihan dalam mendapatkan dan menggunakan barana atau jasa yang ditawarkan tersebut. Faktor - faktor yang mempengaruhi keputusan membeli konsumen akan suatu produk dapat berasal dari dalam diri konsumen maupun bersasal dari luar diri konsumen (Kusumastuti, 2011). Dari berbagai faktor yang mempengaruhi konsumen 
dalam melakukan pembelian produk atau jasa biasanya konsumen selalu mepertimbangkan kualitas, pemasaran dan harga yang sudah dikenal sebagai penilaian dari masyarakat.

Faktor pertama yang mempengaruhi keputusan pembelian adalah persepsi kualitas produk menurut Habibah \& Sumiati (2016) melakukan penelitian tentang pengaruh kualitas produk dan harga terhadap keputusan pembelian produk kosmetik. Hasil penelitian tersebut menunjukkan bahwa persepsi kualitas produk dan harga berpengaruh secara simultan terhadap keputusan pembelian. Dalam penelitian tersebut dijelaskan bahwa kualitas produk adalah keseluruhan barang dan jasa yang berkaitan dengan keinginan konsumen, dan keunggulan barang terbukti layak diperjualbelikan.

Faktor kedua yang mempengaruhi keputusan pembelian adalah persepsi harga. Harga adalah nilai tukar suatu barang atau jasa dengan satuan uang yang disepakati antara penjual dan pembeli (Panjaitan, Andjarwati, Sumiati, \& Panjaitan, 2019). Harga merupakan faktor yang penting digunakan sebagai nilai dari suatu produk yang akan dipasarkan perusahan dan kemudian menimbulkan persepsi yang berbeda pada masing-masing individu (Schiffman \& Kanuk, 2008). Persepsi harga merupakan penilaian terhadap harga pada suatu manfaat produk dikatakan mahal, murah, atau biasa-biasa saja dari setiap individu berbeda, karena tergantung pada setiap individu yang dilatarbelakangi oleh lingkungan dan kondisi individu (Schiffman \& Kanuk, 2008). Artinya harga menjadi salah satu penilaian yang dipertimbangkan dalam pemasaran, hal tersebut karena pandangan masyarakat berbeda-beda mengenai penilaian suatu harga. Dalam menghadapi persaingan diantara perusahaan harga sebagai penentu nilai suatu produk, pada penerapannya harga yang ditetapkan oleh perusahaan harus tepat dan sesuai dengan daya beli konsumen maka keputusan pembelian akan dijatuhkan pada produk tersebut.

Faktor yang ketiga mempengaruhi konsumen dalam pembelian adalah promosi, perusahaan menggunakan promosi untuk memicu transaksi, sehingga konsumen mau membeli suatau produk tertentu secara agresif menjualnya. Selain itu promosi mampu merangsang permintaan akan suatu produk. Dengan promosi tersebut diharapkan konsumen mau mencoba produk tersebut dan mendorong konsumen yang sudah ada agar membeli produk lebih sering lagi sehingga akan terjadi pembelian ulang.

Promosi sebagai penunjang untuk meningkatkan pembelian, promosi adalah suatu komunikasi informasi penjual dan pembeli yang bertujuan untuk merubah sikap dan tingkah laku pembeli, yang tadinya tidak mengenal menjadi mengenal sehingga menjadi pembeli dan tetap mengingat produk tersebut (Saladin, 2002) promosi sebagai sarana penunjang barang dan jasa yang sudah dikenal efektifitasnya. Promosi yang unik, terutama yang menggunakan 
media -media yang kreatif, menjadikan salah satu faktor yang dapat mempengaruhi konsumen dalam melakukan pembelian produk. Promosi merupakan faktor penting dalam mewujudkan tujuan penjualan suatu produk agar konsumen bersedia menjadi langganan. Mereka terlebih dahulu harus mencoba atau meneliti barang - barang yang di produksi oleh perusahaan, akan tetapi mereka tidak akan melakukan hal tersebetut, jika kurang yakin terhadap barang tersebut.

Salah satu perusahaan yang turut memperhatikan faktor - faktor di atas adalah Sophie Paris. Sophie Paris adalah perusahaan fashion di Indonesia yang berdiri di Jakarta pada tahun 1995. Perusahaan ini mendistribusikan pakaian, aksesoris, dan kosmetik dengan metode penjualan langsung. Bruno Hasson adalah pemilik brand Sophie Paris yang mempunyai kemampuan desain yang tinggi, beliau lulusan Institut Superiuer des Techniques d'OutreMer (Istom), sebuah institut pertanian milik pemerintah Perancis. Sophie Paris menyediakan berbagai macam jenis Tas terutama tas wanita dan anak - anak, produk tas yang mereka produksi termasuk produk unggulan dengan bahan baku yang terbaik sehingga menghasilkan sebuah produk yang mampu bersaing dengan produk yang di produksi oleh perusahaan asing. Sophie Paris yang telah lama berdiri terus mengembangkan inovasi dengan memprosuksi tas yang dengan model model update terus mengikuti perkembangan tren yang ada di masyarakat dan yang paling utama adalah Sophie Paris mampu menyediakan produk yang memiliki kualitas yang baik dengan harga yang yang dapat dijangkau oleh semua kalangan masyarakat mulai dari kalangan menengah kebawah sampai kalangan menengah keatas.

Tabel 1

Top Brand Produk Tas Wanita di Indonesia

\begin{tabular}{cccc}
\hline NO & MEREK & TBI 2019 & KET \\
\hline $\mathbf{1}$ & Sophie Paris & $26.8 \%$ & TOP \\
\hline $\mathbf{2}$ & Elizabeth & $25.6 \%$ & TOP \\
\hline $\mathbf{3}$ & Fladeo & $8.1 \%$ & \\
\hline $\mathbf{4}$ & Zara & $3.1 \%$ & \\
\hline
\end{tabular}

Sumber: topbrand-award.com (2019)

Berdasarkan topbrand-award.com pada tahun 2019, dalam kategori perlengkapan pribadi wanita dalam jenis tas wanita Sophie Paris menempati peringkat pertama dari 5 brand tas yang saat ini bersaing di pasar Indonesia (Brand dengan tingkat TBI lebih dari 10\% merupakan (TOP Brand) hal ini menandakan bahwa Sophie Paris merupakan salah satu brand tas ternama asal Indonesia yang mampu mengungguli perusahaan tas dari luar negeri. 
Penelitian ini bertujuan untuk mengetahui pengaruh persepsi kualitas produk, persepsi harga, dan promosi secara parsial terhadap keputusan pembelian Tas Sophie Paris pada mahasiswa di Universitas 17 Agustus 1945 Surabaya; mengetahui pengaruh persepsi kualitas produk, persepsi harga, dan promosi secara simultan terhadap keputusan pembelian Tas Sophie Paris pada mahasiswa di Universitas 17 Agustus 1945 Surabaya; mengetahui variabel yang paling berpengaruh dominan antara persepsi kualitas produk, persepsi harga, dan promosi terhadap keputusan pembelian Tas Sophie Paris pada mahasiswa di Universitas 17 Agustus 1945 Surabaya.

\section{METODE}

Metode yang digunakan pada penelitian ini merupakan metode kuantitatif dengan teknik pengumpulan data menggunakan kuesioner skala likert yang terdiri dari 5 skala. Populasi dari penelitian ini adalah seluruh mahasiswa Universitas 17 Agustus 1945 Surabaya sejumlah 10.686 mahasiswa. Metode pengambilan sampel yang digunakan dalam penelitian ini adalah cluster random sampling. Dasar dalam pengambilan jumlah sampel ditentukan berdasarkan rumus Slovin dengan probabilitas 0,1 . Sehingga didapatkan sebanyak sample sebanyak 100 respondem.

Variabel bebas dalam penelitian ini adalah Persepsi Kualitas produk (X1), Persepsi Harga (X2), Promosi (X3). Persepsi Kualitas menurut Kotler \& Amstrong (2008) mendefinisikan persepsi proses dimana orang memilih, mengatur dan menginpretasikan informasi untuk membentuk gambaran dunia yang berarti. Menurut Kotler \& Amstrong (2008) terdapat 6 dimensi kualitas produk yang perlu diperhatikan : (1) Mutu Kinerja (Performance), (2) Keandalan (reliability), (3) Keistimewaan (feature), (4) Daya tahan (Durability), (5) Mutu kesesuaian (conformance quality), (6) Gaya (Style).

Persepsi Harga (X2) menurut Kotler \& Amstrong (2008) merupakan suatu pendapat atau penilaian konsumen tentang harga dari sesuatu yang akan diberikan untuk mendapatkan produk berupa barang atau jasa yang telah ditawarkan perusahaan dan yang akan dimiliki oleh konsumen. Menurut Kotler \& Amstrong (2008) indikator dari persepsi harga adalah Keterjangkauan harga, (2) Potongan harga, (3) Kesesuaian harga dengan kualitas, (4) Daya saing harga, (5) Promosi diskon.

Menurut Kotler \& Amstrong (2008) Promosi adalah suatu kegiatan didalam perusahaan yang bertujuan untuk menginformasikan kepada konsumen agar tertarik untuk membeli jasa atau barang yang perusahaan tawarkan. Menurut Kotler \& Amstrong (2008) indikator yang digunakan dalam variable promosi adalah : (1) Iklan (Advertising), (2) 
Penjualan Perorangan (Personal Selling), (3) Promosi Penjualan (Sales Promotion), (4) Hubungan Masyarakat (Public relation), (5) Informasi Mulut ke Mulut (Word of Mouth), (6) Surat Pemberitahuan Secara Langsung (Direct marketing).

Sedangkan variabel terikat dalam penelitian ini adalah Keputusan pembelian (Y). Menurut Kotler \& Amstrong (2008) keputusan pembelian adalah tindakan yang dilakukan konsumen untuk melakukan pembelian sebuah produk dari berbagai alternatif. Oleh karena itu, pada pengambilan keputusan pembelian konsumen harus melewati proses pemilihan yang diambil salah satu dari beberapa alternatif penyelesaian masalah dengan tindak lanjut yang nyata. Setelah itu konsumen dapat melakukan evaluasi pilihan dan kemudian dapat menentukan sikap yang akan diambil selanjutnya. Menurut Kotler \& Amstrong (2008) Adapun indikator dari keputusan pembilian adalah (1) Selera konsumen, (2) Pengalaman konsumen, (3) Keyakinan konsumen, (4) Penilaian konsumen.

\section{HASIL DAN PEMBAHASAN}

\subsection{Hasil dan Pembahasan secara Parsial}

Analisis ini menguji apakah persepsi kualitas produk, persepsi harga, dan promosi secara parsial berpengaruh terhadap keputusan konsumen dalam pembelian tas Sophie Paris pada mahasiswa di Universitas 17 Agustus 1945 Surabaya.

Tabel 2

Hasil Uji t

\begin{tabular}{cccc}
\hline NO & MEREK & TBI 2019 & KET \\
\hline $\mathbf{1}$ & Model Anova & $\mathbf{t}_{\text {hitung }}$ & sig. \\
\hline $\mathbf{2}$ & $\begin{array}{c}\text { Persepsi } \\
\text { kualitas produk } \\
(\mathrm{X} 1)\end{array}$ & 2,221 & 0,029 \\
& & \\
\hline $\mathbf{3}$ & $\begin{array}{c}\text { Persepsi harga } \\
(\mathrm{X} 2)\end{array}$ & $-1,487$ & 0,140 \\
\hline $\mathbf{4}$ & Promosi (X3) & 4,722 & 0,000 \\
\hline
\end{tabular}

Sumber: olahan peneliti

Dari hasil uji t pada tabel 2 dapat dilihat bahwa Persepsi kualitas produk (X1) $t_{\text {hitung }}$ $=2,221>t_{\text {tabel }}=1.29007$ dan signifikansi $p$-value $=0,029<0,1$, maka dapat disimpulkan bahwa Variabel bebas Persepsi kualitas produk (X1) berpengaruh positif signifikan secara parsial terhadap keputusan pembelian tas Sophie Paris pada mahasiswa di Universitas 17 Agustus 1945 Surabaya.

Hasil uji penelitian $t_{\text {hitung }}$ menunjukkan hasil yang positif artinya bahwa pengaruh persepsi kualitas produk searah terhadap keputusan pembelian. Maka apabila terjadi 
penambahan positif dari pengaruh persepsi kualitas produk yang ditawarkan tas Sophie Paris, tentunya akan mengakibatkan peningkatan keputusan pembelian.

Dari hasil uji t pada tabel 2 dapat dilihat bahwa Persepsi harga $(X 2) t_{\text {hitung }}=-1,487<$ $\mathrm{t}_{\text {tabel }}=1.29007$ dan signifikansi $\mathrm{p}$-value $=0,140<0,1$, maka dapat disimpulkan bahwa variabel bebas Persepsi harga (X2) tidak berpengaruh signifikan secara parsial terhadap keputusan pembelian tas Sophie Paris pada mahasiswa di Universitas 17 Agustus 1945 Surabaya.

Persepsi Harga menentukan seberapa tepat persepsi konsumen terhadap penilaiannya pada suatu produk dari perusahaan tertentu sehingga menarik perhatian konsumen dan berakhir pada keputusan pembelian. Pada penelitian ini Pengaruh Persepsi Harga terhadap keputusan pembelian menunjukkan arah negatif, artinya semakin tinggi penilaian konsumen terhadap harga suatu barang maka semakin rendah keputusan konsumen untuk melakukan pembelian.

Dari hasil uji $\mathrm{t}$ pada tabel 2 dapat dilihat bahwa Promosi $(X 1) t_{\text {hitung }}=4,722>t_{\text {tabel }}=$ 1.29007 dan signifikansi p-value $=0,000<0,1$, maka dapat disimpulkan bahwa Variabel bebas Promosi (X3) berpengaruh signifikan secara parsial terhadap keputusan pembelian tas Sophie Paris pada mahasiswa di Universitas 17 Agustus 1945 Surabaya.

Promosi merupakan bagian penting dari pemasaran produk, karena pihak perusahaan berharap dengan promosi yang baik dan sesuai dengan keinginan konsumen dapat meningkatkan pembelian berdasarkan ketertarikan individu terhadap promosi tersebut. Pengaruh Promosi terhadap keputusan pembelian adalah searah yang artinya jika Promosi dilakukan dengan baik dan menarik, maka keputusan pembelian yang dilakukan oleh mahasiswa pada produk tas Sophie Paris akan meningkat. Hasil dalam penelitian ini sejalan dengan hasil penelitian terdahulu yang dilakukan Ratnaningrum (2016) yang menunjukkan bahwa variable promosi mempunyai pengaruh yang positif signifikan terhadap keputusan pembelian

\subsection{Hasil dan Pembahasan secara Simultan}

Hasil analisis regresi menggunakan SPSS 23 didapatkan $F_{\text {hitung }}=24,210>F_{\text {tabel }}=2,14$ dengan tingkat signifikan $\mathrm{p}$-value $=0,000<0,1$, maka dapat disimpulkan bahwa $\mathrm{H}_{0}$ ditolak atau $\mathrm{H}_{\mathrm{a}}$ diterima yang berarti bahwa persepsi kualitas produk (X1), persepsi harga (X2), dan promosi (X3) secara simultan berpengaruh terhadap keputusan konsumen dalam pembelian tas Sophie Paris pada mahasiswa di Universitas 17 Agustus 1945 Surabaya

Hasil penelitian ini berarti mendukung hipotesis yang diajukan yang berbunyi “Diduga persepsi kualitas produk, persepsi harga, dan promosi secara simultan berpengaruh 
terhadap keputusan konsumen dalam pembelian tas Sophie Paris pada mahasiswa di Universitas 17 Agustus 1945 Surabaya".

3.3 Pengaruh yang paling dominan diantara persepsi kualitas produk, persepsi harga, Promosi, terhadap keputusan pembelian pada mahasiswa di Universitas 17 Agustus 1945 Surabaya.

Berdasarkan hasil uji secara parsial (uji t) yang dilakukan oleh peneliti menunjukkan bahwa Promosi mempunyai pengaruh paling dominan, karena memiliki nilai signifikansi 0,000. Sehingga promosi memiliki pengaruh paling besar terhadap keputusan pembelian tas Sophie Paris pada mahasiswa di Universitas 17 Agustus 1945 Surabaya.

\section{KESIMPULAN DAN IMPLIKASI}

\subsection{Kesimpulan dalam penelitian ini adalah:}

a. Persepsi kualitas produk dan promosi memiliki pengaruh yang signifikan terhadap keputusan pembelian tas Sophie Paris pada mahasiswa di Universitas 17 Agustus 1945 Surabaya. Namun, presepsi harga tidak memiliki pengaruh yang signifikan terhadap tas Sophie Paris pada mahasiswa di Universitas 17 Agustus 1945 Surabaya.

b. Persepsi kualitas produk, persepsi harga, dan promosi secara simultan berpengaruh secara signifikan terhadap keputusan konsumen dalam pembelian tas Sophie Paris pada mahasiswa di Universitas 17 Agustus 1945 Surabaya.

c. Promosi berpengaruh paling signifikan terhadap keputusan konsumen dalam pembelian tas Sophei Paris pada mahasiswa di Universitas 17 Agustus 1945 Surabaya. arti bahwa promosi berpengaruh signifikan terhadap keputusan pembelian

\subsection{Saran dalam penelitian ini adalah :}

a. Bagi pihak perusahaan tas Sophie Paris Berdasarkan hasil penelitian, presepsi harga tidak berpengaruh secara signifikan terhadap keputusan pembelian tas shope paris. Oleh karena itu pihak perusahaan disarankan untuk memberikan variasi harga sesuai dengan segmentasi pasar yang dituju mulai dari kelas atas, menengah maupun kelas bawah.

b. Bagi peneliti selanjutnya

Untuk menyempurnakan hasil penelitian, Peneliti selanjutnya diharapkan dapat menambahkan atau mengembangkan variabel lain selain dari variabel yang digunakan pada penelitian ini yang diduga mempengaruhi keputusan pembelian konsumen seperti persepsi kualitas produk, persepsi harga, dan promosi. 


\section{REFERENSI}

Kerlinger (2006), Asas-Asas Penelitian Behaviour, Edisi 3, Cetakan 7, Yogyakarta, Gadjah Mada University Press.

Kotler, Philip dan Amstrong, (2008), Manajemen Pemasaran, Edisi 13, Jakarta, Erlangga.

Kusumastuti, A (2011), Pengenalan Pola Gelombang Khas dengan Interpolasi, Malang, Universitas Islam Negri Maulana Malik Ibrahim.

Panjaitan, F. A., Andjarwati, T., Sumiati, \& Panjaitan, H, (2019, July), "The Influence of Quality of Services, Innovation of Products, Prices and Trust on Customer Satisfaction Telkomsel In Surabaya", ACHITS, 1-10. doi: 10.4108/eai.30-7-2019.2287754.

Ratnaningrum, Hesti, (2016), “Pengaruh Promosi, Harga, dan Kualitas Produk Terhadap Keputusan Pembelian Bahan bakar Minyak Jenis Pertalite di Kota Yogyakarta", Yogyakarta ,Fakultas Keguruan dan Ilmu Pendidikan, USD.

Schiffman, Leon dan Kanuk L. Leslie, (2008), Perilaku Konsumen, Jakarta, PT INDEKS.

Sugiyono, (2008), Metodelogi Penelitian Kuantitatif, Kualitatif dan R \& D. Bandung, Alfabeta. Sumiati, U. H. (2016, 330), “Pengaruh Kualitas Produk Dan Harga Terhadap Keputusan Pembelian Produk Kosmetik Wardah Di Kota Bangkalan Madura. Jurnal Ekonomi \& Bisnis", Vol. 1 No. 1, Hal, 31-48.

T. Ayuningtias, and H. Waluyo, "Pengaruh Kualitas Produk, Citra Merek dan Iklan Terhadap Keputusan Pembelian Kartu XL Prabayar di Kota Semarang (Studi Kasus pada Pengguna Kartu XL Prabayar di Kota Semarang)", Jurnal Ilmu Administrasi Bisnis, Vol. 6, No. 3, pp. 11-16, Jun. 2017.

Tjiptono, Fandy (2008). Strategi Pemasaran, Edisi Ketiga, Yogyakarta, Andi.

Top Brand (2019), „Top Brand Index Fase 2 2019”, available at: https://www.topbrandaward.com/top-brand-index/?tbi_find=Sophie\%20Paris

Yana Sari, Merry (2017), “Pengaruh Persepsi Kualitas Produk Terhadap Keputusan Pembelian Pada Produk Hand And Body Lotion Vaseline di Bandar Lampung", Bandar Lampung, Fakultas Ekonomi dan Bisnis Universitas Bandar Lampung, UBL. 